Polgári Szemle, 17. évf. 4-6. szám, 2021, 404-408., DOI: 10.24307/psz.2021.1228

\author{
Filczer-Plósz Krisztina
}

\title{
A Közös Agrárpolitika rendszere
}

\section{The Common Agricultural Policy System}

\begin{abstract}
ÖSSZEFOGLALÁs
Jelen recenzió Halmai Péter A Közös Agrárpolitika rendszere című, 2020-ban megjelent művének ismertetésére vállalkozik. A kötet $\mathrm{A}$ modern állam gazdasági szerepének legújabb dimenziói elnevezésű Ludovika Kiemelt Kutatóműhely keretében folytatott kutatások eredménye. A tanulmánykötet célja a Közös Agrárpolitika rendszerének közérthető megismertetése, mélyebb elemzése és rendszerezése. Alkotói az agrárpolitika területén dolgozó vezető szakemberek és egyetemi oktatók. A nyolc tanulmányt felölelő könyv olvasmányos, ugyanakkor magas tudományos színvonalat képviselve tankönyvként is kiválóan használható.
\end{abstract}

Journal of Economic Literature (JEL) kódok: A12, E02, G28

Kulcsszavak: agrárgazdaság, mezőgazdasági finanszírozás, oktatás, nemzetközi kapcsolatok

\section{SumMary}

This book review undertakes to present 'The Common Agricultural Policy System', a work by Péter Halmai, published in 2020. This volume is the result of research conducted within the framework of the Ludovika Special Research Workshop entitled 'The Latest
Dimensions of the Economic Role of the Modern State'. This collection of studies aims at providing a clear understanding, deeper analysis and systematisation of the Common Agricultural Policy system. It is written by leading experts and academics working in the field of agricultural policy. The handbook, comprising eight studies, makes an interesting read but also represents high scientific quality, making it an excellent textbook.

Journal of Economic Literature (JEL) codes: A12, E02, G28

Keywords: agricultural economics, agricultural funding, education, international relations

\section{BevezetÉs}

Halmai Péter Széchenyi-díjas magyar közgazdász, egyetemi tanár, a Magyar Tudományos Akadémia levelező tagja, akinek a fő kutatási területei a nemzetközi gazdaságtan, a makroökonómia, az összehasonlító gazdaságtan, illetve az agrár-közgazdaságtan. Halmai Péter kiemelkedő eredményeket ért el az európai integráció makroökonómiájában, a potenciális növekedés irányzatai, az európai növekedési és felzárkózási modell sajátosságai, a pénzügyi és

Filczer-Plósz Krisztina, PhD hallgató, NKE KDI (krisztina.filczer@gmail. com). 


\section{Könyvrecenzió}

gazdasági válság növekedési hatásai, a strukturális reformok, továbbá az általa bevezetett tudományos meghatározás, a mélyintegráció hatásmechanizmusai feltárása terén. Halmai Péter számos magyar és idegen nyelven megjelenő tanulmánnyal és tankönyvvel gazdagította az akadémiai életet.

Halmai Péter legújabb, A Közös Agrárpolitika Rendszere című kötete „A modern állam gazdasági szerepének legújabb dimenziói” elnevezésű Ludovika Kiemelt Kutatóműhely keretében végzett kutatások keretében jelent meg 2020ban, a Dialog Campus kiadónál.

A vidékfejlesztési támogatások révén az Európai Unió hozzájárul a tagállamokban a mezőgazdaság és az erdőgazdálkodás versenyképességének javítása, a környezet és a vidék védelme, a vidéki életminőség javitása és a vidéki gazdaság diverzifikációja, valamint a helyi vidékfejlesztési megközelítések előmozdítása céljából végzett beruházásokhoz. Az Unió támogatja a tagállamok vidékfejlesztési programjait, amelyek az EU integráció kiemelt területét képezik. A Közös Agrárpolitika (KAP) dinamikus szakpolitika és reformok sorozatán keresztül alakították ki úgy, hogy megfeleljen az európai mezőgazdaság előtt álló új kihívásoknak. Az EU azért hozta létre és hajtja végre a Közös Agrárpolitikát, hogy meg tudjon felelni a különböző alapvető kihívásoknak, mint például:

- az élelmezésbiztonság szavatolása minden európai polgár számára,

- a globális piacok és az árak ingadozásainak kezelése,

- a vidéki területek fejlődésének fenntartása Unió-szerte,

- a természeti erőforrások fenntarthatóbb módon történő felhasználása, vagy

- az éghajlatváltozás mérsékléséhez történő hozzájárulás.

A Halmai Péter szerkesztésében megjelent kiadvány tartalmának és szerkesztésének köszönhetően kitűnően használható kötet született. Nemcsak az agrárfelsőoktatás számára, hanem közgazdasági, külgazdasági és jogi jellegü felsőoktatási intézmények, valamint az európai integráció témakörei iránt érdeklődő szakemberek részére is. A szerzők közérthető formában elemezték az EU agrárrendszerét, az európai agrárintegrációt, továbbá a nemzetközi agrárkereskedelem-politikát. A kötet értékét növeli, hogy az alkotók az agrárpolitika működtetése területén dolgozó vezető szakemberek és egyetemi oktatók, így a legaktuálisabb ismereteket is be tudták építeni a műbe.

\section{A KÖTET TARTALMI FELÉPÍTÉSE}

A könyv kitűzött fő célja az európai integráció szélesebb témakörén belül a Közös Agrárpolitika rendszerének megismertetése, mélyebb elemzése és rendszerezése. A KAP az összes uniós tagország közös szakpolitikája. Irányítása és finanszírozása uniós szinten, uniós költségvetési források felhasználásával történik. Maga a KAP témaköre folyamatosan időszerű, hiszen az unió érdeke, hogy az európai mezőgazdaság jövőjét biztosítsa. Ennek okán a KAP az évek során továbbfejlődött, igazodva a változó gazdasági viszonyokhoz, valamint a polgárok elvárásaihoz és szükségleteihez. Az EU Miniszterek Tanácsa, az EU Parlament és a Bizottság a horvát elnökség végén megállapodtak abban, hogy a Közös Agrárpolitika reformját két évvel elhalasztják, többek között a jelenlegi COVID 19 okozta világjárvány miatt. Az új KAP-ról eredetileg 2020-ban kellett volna megállapodni és 2021 elején kellene hatályba lépnie.

A kötet kéziratai eredetileg a Közös Agrárpolitika születése, az 1958. évi stresai konferencia hatvanadik évfordulójának évében, 2018-ban készültek el. 2020 tavaszán a szerzők lehetőséget kaptak a szöveg időszerűsítésére.

A könyv legelején a szerkesztő ${ }^{1}$ rövid bevezetése olvasható. A kötet nyolc tanulmányt ölel fel, amelyek az alábbi területeket foglalják magukba:

- a Közös Agárpolitika (KAP) rendszerének fó sajátosságai, az eredeti modell alapproblémái;

- a KAP reformjainak hajtóerői, fö fejleményei egészen 2020-ig;

- a KAP és a nemzetközi agrárkereskedelempolitika;

- az EU keleti bővülésének következmé- 


\section{Könyorecenzió}

nyei, a KAP és a reform adaptálása hazánkban, illetve más új tagállamokban;

- piacszabályozás, piaci szervezetek mechanizmusa;

- a ténylegesen működő agrárstruktúra bemutatása;

- az EU élelmiszer- és agrártermék-szabályozási rendszere és minőségpolitikája.

A fejezetek diagramokkal, táblázatokkal és ábrákkal színesítve segítik az adott témák megértését. A fejezetek végén a felhasznált irodalom és az áttekintendő fogalmak támogatják az olvasót a kívánt részben való elmélyülésben.

A kötet fejezetei elméleti és gyakorlati ismereteket adnak az uniós agrárpolitikáról, annak történetéről, fejlődéséről, gazdasági és kereskedelmi viszonyairól. Természetesen a hazai agrárgazdaság vonatkozásai, a csatlakozás feltételei, a beilleszkedés fó tényezői is szerepelnek a kötetben. Képet kapunk a vidékfejlesztési programokról és általános jellemzőiről is. Ugyanakkor a megfelelő helyeken a szerzők jelzik az tagállamok felelősségét az adott KAP rendszer nemzeti alkalmazása tekintetében.

A könyv első két fejezetét a szerkesztő, Halmai Péter írta. A Közös Agrárpolitika rendszere című szerkezeti egységben a szerző az európai mezőgazdaság szerkezetének jellemzőit tárja fel, s összehasonlítja a magas versenyképességü tengerentúli országok agrárgazdaságainak a jellemzőivel. Halmai kiemeli, hogy „az EU-országok agrártermelése a végtermék-elóallitásán túl, a vidéki közösségek fenntartásának célját is szolgálja”. A közös, majd egységes piac rendszerében az agrárgazdaságban közös piacrend kiépítése szükséges. A KAP alapvető jellemzője a közös finanszírozás, amelynek keretéről, alakulásáról (csökkenéséről), annak okairól és mechanizmusairól részletes elemzést kapunk. A második fejezet $\left(A K{ }_{0}-\right.$ zös Agrárpolitika reformja) a reformok folyamatát elemzi. A mélyreható változtatások révén a KAP rendszere többlépcsős átalakításon ment keresztül. A kötetben helyet kapott a 2013-2020 közötti rendszer bemutatása és a 2020 utáni fejlemények körvonalazása. A fejezetben a szerző több megoldási lehetőséget is felvázol a KAP jövőjét illetően. Álláspontja szerint a piaci koordináció szerepe lesz meghatározó a további reform folyamatában.

Elekes Andrea a Közös Agrárpolitika kereskedelempolitikai összefüggéseit ${ }^{2}$ mutatja be. Kiemeli, hogy az Európai Unió sokáig elzárkózott a GATT keretei közötti tárgyalóktól, azonban az Uruguay-forduló részeként elfogadott Mezőgazdasági Megállapodás áttörést jelentett a kereskedelemtorzító intézkedések kiküszöbölésében. Részletezi a megállapodást és az azt követő további agrárkereskedelmi fejleményeket. A Szerző bemutatja, hogy az Unió agrárkereskedelem-politikájának kibontakozása milyen preferenciális kapcsolatok kiépítésével járt. Azok főbb jellemzőit, közöttük partnerségi megállapodásait is, áttekinthetően összefoglalva tárgyalja.

Vásáry Miklós „A Közös Agrárpolitika átvétele az új tagállamokban" című fejezetében az Unió keleti kibővülésére vonatkozó összefüggéseit tárgyalja. Fontos szerepet kap a fejezetben a hazai vonatkozások bemutatása is. A csatlakozási kritériumok tárgyalását követően a magyar agrárcsatlakozás ${ }^{3}$ előzményeit, annak menetét és feltételeit tárgyalja. A magyar agrárgazdálkodás fő folyamatainak adatait elemezi, s rávilágít a fó ágazatok termelésének arányváltozására a legutóbbi 20 év tekintetében. Körvonalazza a jövőbeni nélkülözhetetlen szerkezeti változásokat, mind hazánk, mind a többi keleti tagállamok számára. Kiemeli a KAP támogatásainak lehetséges, a nemzeti implementációtól sem független pozitív szerepét a szükséges folyamatok előmozdítása tekintetében.

Nagy Attila a „Közös piaci szervezetek, közös piacszervezés" című fejezetében az egyes mezőgazdasági ágazatok eltérő piacszabályozását tekinti át. A legutóbbi agrárpiaci reform markáns módosításait, a piaci folyamatok változásainak rendszerét és támogatási programjait részletesen bemutatja a fó ágazatok tekintetében. A piactámogatás keretében a magyar érintettséget is elemzi, és számokkal alátámasztva mutatja be az adott támogatási programok megvalósulását.

Maácz Miklós az áltata írt fejezetben a vidékfejlesztés rendszerét ${ }^{4}$ tekinti át. Megvilágítja a vidék fogalmát és a vidéki területek lehatárolását, amely a vidékfejlesztési támogatások igény- 


\section{Könyvrecenzió}

bevételének alapja. Részletesen ismerteti, hogy miben tér el a vidékfejlesztés a területfejlesztéstől, miközben azonos elérendő stratégiai célokkal rendelkeznek. Képet kapunk az EU szintű átfogó célokról és a vidékfejlesztési program tartalmi elemeiről, a fejlesztési programok hazai struktúrájának a tükrében.

Pál Zsombor tanulmánya az Unióban ténylegesen működő agrárstruktúrát mutatja be, számokkal és diagramokkal együtt. A részletes megalapozás lehetőséget kínál az egyes tagállamok összehasonlítására. A Szerző a makrogazdasági mutatókat alapul véve ír a keleti és déli, valamint a nyugati és északi tagállamok közötti eltérésekről. Halmai Pétert idézve „A mezógazdaság nemzetgazdasági szerepe jelentös különbségeket mutat a tagországok között”. Az egyes tagállamokat összehasonlítja különböző mutatók, úgymint a termelékenység, a jövedelem vagy az élelmiszer-fogyasztás alapján.

Szegedyné Fricz Ágnes az élelmiszer-biztonsági, minőségi kérdéseket ${ }^{5}$ járja körbe. A vertikális és horizontális szabályozás fontosságába avatja be az Olvasót, valamint a szabványosítási munka szerepére is rávilágít. Az EU-n belül az emberi egészség védelme magas szinten elvárás, és ennek megfelelően a fejezetben megismerhetjük az ennek érdekében létrehozott szabályozást, mind állattenyésztési, mind növényügyi, mind higiéniai területeken. A fejezet további nagyon fontos témája a genetikailag módosított organizmusok témaköre. Az EU 1990 óta magas szinten szabályozta a génmódosított növények termesztését és forgalmazását. Hazánk kiemelten fontos stratégiai kérdésként kezeli a géntechnológiával módosított növényekkel kapcsolatos tevékenységek szabályozását és a magyar mezőgazdaság GMO-mentes státuszának megőrzését. A bizalmat elősegítheti, hogy előbbiek szigorú szabályozás oltalma alatt állnak.

\section{KÖVETKEZTETÉSEK}

Mindent egybevetve a kötet alapvetően kézikönyv, azonban tankönyvként is megállja a helyét. A Szerzők a tárgyalt témakörök magas szintű ismeretével, egyidejüleg gyakorlati szakpolitikai tapasztalatokkal is rendelkeznek. Az egyes problémakörök megértéséhez szükséges elméleti háttér alaposan bemutatásra került mindegyik fejezetben, jellemzően közgazdasági összefüggésekkel és szemléltető illusztrációkkal alátámasztva. A mű fontos értéke a tárgyalt témakör szélesebb összefüggésekbe történő beillesztése. ${ }^{6}$ A könyv olvasmányos, ugyanakkor egyidejüleg magas tudományos színvonalat képvisel. Az egyes fejezetek külön-külön is felhasználhatók, így az érdeklődő a saját kíváncsisága szerint is válogathat a témakörökből. Ám a fejezetek úgy épültek egymásra, mind stílusuk, mind a szemléltető eszközök (ábrák, táblázatok) tekintetében, mintha egyetlen szerző által írott művet forgatna az Olvasó. Az európai integráció agrárpolitikai területét kiválóan összefoglaló tanulmánykötet jól szolgálhatja az érintett szakembereken túl az európai integráció, azon belül az agrárintegráció iránt érdeklődő olvasókat is.

Halmai Péter (szerk.): A Közös Agrárpolitika rendszere. Ludovika Egyetemi Kiadó, Budapest, 2020.

ISBN: 9789635312825

Terjedelem: 342 oldal

\section{JEGYZETEK}

1 A kötet szerkesztője számos, a témakört rendszerező mű szerzője: Halmai P. (1995, 1996, 2001a, 2001b, 2002, 2004a, 2007, 2010, 2015a, 2020c), illetve Elekes - Halmai - Uzonyi - Vásáry (2003), Elekes - Halmai (2009).

E témakör előzményeiről ld. bővebben: Halmai, P. Elekes, A. (2001, 2003) Elekes - Halmai (2005, 2008).

3 A KAP átvétele magyar agrárgazdaságra gyakorolt hatásairól ld. pl.: Halmai, P. (2003, 2004b, 2006), Halmai - Pálovics (1997)

4 A témakör szélesebb összefüggéseiről ld. pl.: Csatári - Halmai - Tóth (2009), Csatári - Halmai - Vásáry (2010)

5 A témakör közgazdaságtani összefüggéseiről ld.: Elekes - Halmai - Uzonyi (2007).

6 Annak alapját képezik a kötet szerkesztőjének fontos átfogó integrációgazdaságtani művei. Azok közül a legutóbbi évekből kiemelést igényelnek: Halmai, P. (2014, 2015b, 2017, 2018a, b, c, 2019, 2020a, b, d, e), illetve Halmai - Elekes (2013a, b), Halmai - Vásáry (2010). 


\section{Könyvrecenzió}

\section{FELhasZnÁlt IRODALOM}

Csatári Bálint - Halmai Péter - Tóth Erzsébet (2009): A vidék jövője - az agrárpolitikától a vidékpolitikáig, In: Banczerowski, Januszné; Bárdosi, Vilmosné Horányi Krisztina; Horváth, Csaba; Szemenyei, István; Wagner, Péter (szerk.): Stratégiai kutatások, 2008-2009 : Kutatási jelentések, Budapest, Miniszterelnöki Hivatal, Magyar Tudományos Akadémia

Csatári Bálint - Halmai Péter - Vásáry Viktóra (2010): Új vidékpolitika felé. Változó európai paradigma, növekvó hazai kihívások, In: Szarka, L; Horányi, K; Horváth, Cs (szerk.) (2010) Budapest, Miniszterelnöki Hivatal, Magyar Tudományos Akadémia

Elekes Andrea - Halmai Péter - Uzonyi Györgyné - Vásáry Viktória (2003): Az Európai Unió Közös Agrárpolitikája, Fogalomtár. Budapest, Agroinform

Elekes Andrea - Halmai Péter - Uzonyi Györgyné (2007): Az élelmiszer-biztonság közgazdasági hatásai. Külgazdaság, Vol. 51, No. 11-12. 38-59.

Elekes Andrea - Halmai Péter (2009) The ,hottest topic” of the budgetary review: will the CAP survive? Intereconomics: Review of European Economic Policy 44: 5 pp. 300-308.

Elekes Andrea - Halmai Péter (2013a): Growth Model of the New Member States: Challenges and Prospects, Intereconomics: Review of European Economic Policy 48: 2 Pp. 124-130.

Elekes Andrea - Halmai Péter (2013b): Az új tagállamok növekedési modellje: Kihívások és kilátások, Külgazdaság 57: 7-8. pp. 32-66.

Halmai Péter (1995): Az Európai Unió agrárrendszere, Mezőgazda Kiadó, Budapest

Halmai Péter (1996): Kiigazítás vagy reform? Az európai Közös Agrárpolitika a kilencvenes években. Európa Fórum 4. sz.

Halmai Péter - Pálovits B. (1997): Az EU-tagság agrárgazdasági hatásmechanizmusai. Külgazdaság, 41. évf. 2. sz.

Halmai Péter (2001a): A Közös Agrárpolitika. In: Kende T. - Szűcs T. szerk.: Az Európai Unió politikái. Budapest, Osiris.

Halmai Péter (2001b): A Közös Agrárpolitika (CAP) reformjának elméleti alapjai, Szent István Egyetem, Gödöllő

Halmai Péter (2002): Az Európai Unió agrárrendszere. Budapest, Mezőgazda.

Halmai Péter (2004a): Az agrárgazdaság EU-adaptációja. Várható feszültségek, gazdaság- és társadalompolitikai kihívások, Politikatudományi Szemle XIII: 1-2.
Halmai Péter (2004b): A reform ökonómiája. Budapest, KJK KERSZÖV.

Halmai Péter (2006): A magyar agrárgazdaság EU-beilleszkedése, Fejlesztés és Finanszírozás, 2006/2. sz.

Halmai Péter (szerk.,2007): Az Európai Unió agrárrendszere. Budapest, Mezőgazda.

Halmai Péter (2010): Közös Agrárpolitika. In Kengyel Á. szerk.: Az Európai Unió közös politikái. Budapest, Akadémiai Kiadó

Halmai Péter - Vásáry Viktória (2010): Real convergence in the new Member States of the European Union (Shorter and longer term prospects), European Fournal of Comparative Economics 7: 1 pp. 229-253.

Halmai Péter (2015a): Közös mezőgazdasági politika. In Kende T. szerk.: Bevezetés az Európai Unió politikáiba. Budapest, Wolters Kluwer.

Halmai Péter (2015b): Az európai növekedési potenciál eróziója és válsága, Közgazdasági Szemle 62: 4 pp. 379414.

Halmai Péter (2018a): Az európai növekedési modell kifulladása, Közgazdasági Szemle 65: 2 pp. 122-160.

Halmai Péter (2018b): A Brexit lehetséges gazdasági hatásai, Európai Tükör: az Integrációs Stratégiai Munkacsoport kéthavonta megjelenő folyóirata, XXI: 2 pp. 7-32.

Halmai Péter (2018c): Európai reformok: Többsebességű Európa? Differenciált gazdasági integráció versus átfogó reform, Európai Tükör: az Integrációs Stratégiai Munkacsoport kéthavonta megjelenő folyóirata 21: 3 pp. 21-44.

Halmai Péter (2019): Konvergencia és felzárkózás az euróövezetben, Közgazdasági Szemle 66: 6 pp. 687-712.

Halmai Péter (2020a): Európai gazdasági integráció. Budapest, Dialóg Campus.

Halmai Péter (2020b): Mélyintegráció. A Gazdasági és Monetáris Unió ökonómiája. Budapest, Akadémiai Kiadó.

Halmai Péter (2020c): Közös Agrárpolitika. In Kengyel, Á. szerk.: Az Európai Unió közös politikái. Budapest, Akadémiai Kiadó.

Halmai Péter (2020d): A dezintegráció gazdaságtana. A brexit esete, Közgazdasági Szemle 67: 9 pp. 837-877.

Halmai Péter (2020e): GMU 2.0? Felelősség versus szolidaritás? Külgazdaság, 2020. 9-10. szám 